\title{
The Nexus Among Non-performing Loans, Lending Rates and Financial Performance of Banks in Ghana
}

\author{
Amos Ninson ${ }^{1, ~ *, ~ A u g u s t i n a ~ S i d z a ~}{ }^{1}$, Dominic Ampah ${ }^{2}$ \\ ${ }^{1}$ Finance Directorate, Accra Technical University, Accra, Ghana \\ ${ }^{2}$ Internal Audit Directorate, Accra Technical University, Accra, Ghana
}

Email address:

aninson@gmail.com (A. Ninson), tilysid@yahoo.com (A. Sidza), dominic.ampahyahoo.com (D. Ampah)

${ }^{*}$ Corresponding author

\section{To cite this article:}

Amos Ninson, Augustina Sidza, Dominic Ampah. The Nexus Among Non-performing Loans, Lending Rates and Financial Performance of Banks in Ghana. International Journal of Finance and Banking Research. Vol. 7, No. 5, 2021, pp. 123-132.

doi: $10.11648 /$ j.ijfbr.20210705.13

Received: August 25, 2021; Accepted: September 24, 2021; Published: October 12, 2021

\begin{abstract}
The main purpose of the study was to examine the relationship among non-performing loans, Commercial Banks' lending rate and financial performance of Commercial Banks in Ghana. The time series design was used along with the quantitative research approach. Secondary data on the selected variable and some control variables were accessed from the economic and monetary data base of the Central Bank of Ghana from 2006 to 2019 and used for the analysis. Both theoretical and empirical literature was reviewed to create a research gap for the study. Time series properties of the variables such stationarity and descriptive were done to assess the stability of the time series variables. The Augmented Dickey-Fuller unit-root test was used for the stationarity test since the time series plots indicated no possibility of serious structural breaks. Return on assets before tax, return on equity after tax, Commercial Banks interest rate, inflation and inter-banks interest rate were found to be significant determinants of Non-performing loans in the financial sector of Ghana. It was concluded that simultaneous relationships exist among the level of non-performing loans, Commercial Banks' lending rate and financial performance of Banks in Ghana, hence anyone of them could serve as a lead variable or policy variable in ensuring a stable financial system in Ghana. It was recommended that the management of commercial banks must exploit other avenues of generating income such as direct project financing among others and reduce reliance on interest payment through increase in interest charges.
\end{abstract}

Keywords: Commercial Bank, Lending, Loans

\section{Introduction}

Financial performance is at the heart of every organization of which Commercial Banks are not exception. Commercial Banks are profit motivated banks that engage in financial intermediation with the aim of maximizing return on investment. Commercial Banks occupy a central role in the inter-temporal choice market by linking net lenders with net borrowers. The loanable funds market was predominantly informal before the development of a well-organized and functional financial system and required the physical meeting of the lender and the borrower $[1,2]$. The development of a well-functioning financial system leads to the emergence of financial intermediaries such as banks to mob up excess liquidity from net lenders and makes it available to net borrowers (financial deficit) at a fee called the lending rate (financial surplus) [3]. The main aim of financial intermediation by Commercial Banks is to transfer funds from the net lenders to the net borrower for investment with the view to engendering economic growth and development. The Commercial Bank rewards the net lenders with an interest on their deposits while it charges the net borrower an interest on borrowing. The interest rate on borrowing (lending rate) is a mark-up on the interest rate on deposit and which explains the disparity between lending and borrowing rates.

The existing literature offered two reasons for which banks may maintain high interest spread or margin. One factor is high operation cost which requires higher lending rates over and above the interest on deposit to cover the intermediation cost $[4,5]$. The second is the level and incidence of non- 
performing loans or credit risk which requires high lending rate to compensate for the risky nature of the loans as in the case of Ghana [6]. Despite the close link among the lending rate, Commercial Banks financial performance and the level of non-performing loans in the financial sector of Ghana, the three variables have mostly been studied in isolation with one of them being considered a function of the other. This study examined the relationship among these three financial variables by paying particular attention to the simultaneity among them.

\subsection{Statement of the Problem}

The current structure of the banking sector is that of a financial sector under reform and recovering from restructuring. The past two years have been characterized by several activities that saw a number of banks going into insolvency due mainly to internal factors such as corporate governances and non-performing loans among others. The level of non-performing loans was alarming prior to the bank crisis and subsequent banking sector reform by the central bank, suggests that the level of non-performing loans is falling.

There is also a compelling need to determine whether the reform results in high financial performance of the remaining banks, it has reducing or increasing effects on the level of lending rate and hence on the level of nonperforming loans. While more external factors that are not under the direct control of Commercial Banks are identify as drivers of profitability and non-performing loans, there is the need to understand the consistent relationship that exit among the three main variables themselves. That is, how does interest rate and level of non-performing loans influence profitability of banks in general, and is there a feedback relationship among any of the endogenous variables. The existing empirical literature examines the determinants of these financial variables in isolation, which does not allow for the any possible feedback relationship to be identified [7]. This study intended to examine the relationship among the lending rates of Commercial Banks, the level of non-performing loans and financial performance using a time series data on aggregated bank sector performance from the central bank.

\subsection{Purpose of the Study}

The main purpose of the study was to examine the nexus among non-performing loans, commercial banks' lending rate and financial performance of Commercial Banks in Ghana.

\subsection{Research Objectives}

1) Examine the relationship between non-performing loans and financial performance of Commercial Banks in the financial sector of Ghana.

2) Determine the relationship between lending rate and financial performance of Commercial Banks in the financial sector of Ghana.

3) To examine the relationship between non-performing loans and lending rate of Commercial Banks in the financial sector of Ghana.

\subsection{Research Hypothesis}

1) HO: there is no relationship between non-performing loans and financial performance of Commercial Banks in the financial sector of Ghana.

2) HO: There is no relationship between lending rate and financial performance of Commercial Banks in the financial sector of Ghana.

3) HO: there is no relationship between non-performing loans and lending rate of Commercial Banks in the financial sector of Ghana.

\section{Non-Performing Loans (NPL)}

The Finance literature provides several indicators for the measurement of the performance of a loan which includes consistency in repayment or number of days in default [8]. In terms of consistency of repayment, [9] referred to Nonperforming loans (NPLs) as loans that are not earning income and full payment of principal and interest is no longer expected. In terms of number of days of repayment, the International Monetary Fund (IMF) described a loan as non-performing if it does not generate interest and principal for a minimum of 90 days [10]. The IMF's Compilation Guide on Financial Soundness Indicators offered an extended definition of NPLs which does not make 90 days default payment a strict rule. The IMF's Compilation Guide on Financial Soundness Indicators, states that a loan is nonperforming when payments of interest and/or principal are past due by 90 days or more, or interest payments equal to 90 days or more have been capitalized, refinanced, or delayed by agreement, or payments are less than 90 days overdue, but there are other good reasons such as a debtor filing for bankruptcy to doubt that payments will be made in full [11].

\subsection{Theoretical Framework}

Since the study combined three main constructs in finance, non-performing loans, lending rates and financial performance, no single theory was identified that link all the three, but there were theories that explain every two of them. These theories were adapted and linked to provide a theoretical basis for the study. The Credit Risk Theory and the Anticipated Income Theory were adopted to explain the linkages between systemic risk and non-performing loans which eventually determines the level of interest rate charged by commercial banks and hence the effects on financial performance of banks. Since the study was macro study, using the aggregates commercial banks in Ghana, profitability models such as the Structural Conduct Paradigm and critical resource theories among others were not appropriate. They are micro theories that rest on the individual characteristics of the firms. The profitability of the banks, as a measure of financial performance, was 
traced from the two models since the credit worthiness of the banks and their expected income is key to their own performance. Ability to access more external funding also translates into improved financial performance. Credit risk refers to the risk of experiencing a financial loss due to the decline in the creditworthiness of an entity in a financial transaction [12].

It is mainly that of the lender and includes loss of principal amount and interest payments, which may be complete or partial and can occur from situations such as an insolvent bank unable to return funds to a depositor. The Robert Merton's theory of default or default model is the basic theory of credit risk. Robert proposed a model for assessing the credit risk of a company by characterising the firm's equity as a call option on its assets [13]. Merton stated that, lenders could reduce risk on a loan by performing a credit check on the prospective borrower, require the borrower to take appropriate insurance, such as mortgage insurance or seek security or guarantees of third parties [13]. Where risks are difficult to manage or minimise, the theory posits that the lender request a compensatory premium on the loan in the form of interest charges. That is the higher the risk, the higher will be the interest rate that the debtors will be asked to pay on the debt [14]. The connection with non-performing loans can be traced from the understanding that the higher interest charge predisposes the loan to default, which eventually threatens the financial performance of the bank or the lender.

The [15] using the US commercial banks practice proposed the Anticipated Income Theory. The theory states that, regardless of the nature and character of a borrower's business, the bank should plan the liquidation of the termloan (loan between one to five years) from the anticipated income of the borrower [13]. This theory places emphases on the ability of the bank to advance loan base on the income that the borrower expects both in the short-term and long-term. The amount of loans that a bank advanced to its customers becomes a direct function of the cash flow of the customer, since a loan by the bank gets repaid out of the future income of the borrower through instalments, instead of in a lump sum at the maturity of the loan. Banks advance more loans when the expected incomes of the customers are regular and sustainable. Simply put, the financial performance of the borrowers is key in their access to finance from the banks, which by extension links the financial performance of the banks to that of their customers. When this position is held, then the managers of banks have no incentive to charge high interest that increase the probability of defaults, which will then mean reduce financial performance for the bank. [16] Stated that a low level of NPL indicates a sound financial system, whereas high NPL can indicate a vulnerable financial system. [17] Suggested that a high level of NPL initially affects the individual commercial banks and in the long run, ultimately ruins the financial system and the economy of the entire nation.

The fact that the relationship among the level of nom- performing loans, lending rates and financial performance of banks requires an empirical examination is clear from the positions of the two theories adopted for the study. That is, the credit risk theory expect banks to charge higher interest for risky clients in line with information asymmetry, while the anticipated income theory expect the size of the loans to depend on expected income of the borrower. Since higher interest rate, in theory has adverse effects on performance, the dilemma is what happens to a risky clients that is currently performing by making risky decisions. The firms must, therefore, make interest rate decision based on some additional factors such as their own financial performance and ability to deal with default should it occur.

The steps of Five Cs of Non-performing/Bad Loans

Since [18] stated that, there are five Cs of bad credits that represent the issues used to guard against or prevent bad loans). These are:

a. Complacency

Refers the tendency to assume that because of the things were good in the past, they will be good in the future. For instance, assuming the past loan repayment success since things have always worked out in the past.

b. Carelessness

Indicates the poor underwriting typically evidenced by inadequate loan documentation, lack of current financial information or other pertinent information in the credit files, and lack of protective covenants in the loan agreement. each of these makes it difficult to monitor a borrower's progress and identify problems before they are unmanageable.

c. Communication ineffectiveness

Inability to clearly communicate the bank's objectives and policies. This is when loan problem can arise. Therefore, the bank management must clearly and effectively communicate and enforce the loan policies and loan officers should make management aware of specific problems with existing loans as soon as they occur.

d. Contingencies

Refers to the lenders' tendency to play down or ignore circumstances in which a loan may be in default. It focuses on trying to make a deal work rather than identifying down side risk.

\section{e. Competition}

Involves following the competitors' action rather than monitoring the bank's own credit standards. Banks, however, still have required expertise, experiences, and customer focus to make them the preferred lender for many types of loan. Lending is not just a matter of making loan and waiting for repayment. Loan must be monitored and closely supervised to prevent loan losses [18].

\subsection{Overview of Bank Loans in Ghana}

Since [19] pointed out that a stable banking system is a requirement for an efficient financial intermediation to ensure rapid economic growth. This is achieved through the transformation of funds raised from surplus units into loan assets for deficit units [20]. Number of banks has dropped significantly after the banking sector reforms and now stands 
at 24 commercial banks in Ghana [21].

Banks in Ghana performs the financial intermediary role by mobilizing funds from the general public and other sources to create money for the investment community through loans and overdrafts at market interest rate. Income of banks is mainly generated from the interest they charge on the loans they give out to their customers [22]. Bank loans in Ghana, like most other developing countries, compete with vibrant informal and semi-formal sources of funds such as unregistered money lenders, family and friends and credit unions among others. Micro finance institutions are also alternative sources of formal funds for small and medium scale enterprises based on an entirely different loan repayment structure. Access to formal funds is considered difficult tasks for enterprises of all size categories in Ghana. This, according to empirical evidence, is due to the fact that loans to enterprises in Ghana like all other developing countries are considered risky. The major risk to formal loans in Ghana is the risk of default that could results in the increase in the level of non-performing loans of banks [23].

\subsection{Non-performing Loans (NPLs) Situation in Ghana}

The 2017 Bank of Ghana's Banking Sector Report shed light on the state of non-performing loans in Ghana. The 2018 and 2019 reported on the level of non-performing loans but did not provide the details as was done in the 2017 reports. The 2017 report stressed on the major actors involved in the NPL in Ghana as presented [24]. The private sector was adjudged the sector with the greater share of NPLs in Ghana. According to the report, the private sector, being the largest recipient of outstanding credit balances also accounted for greater proportion of banks' NPLs. The share of private sector NPLs in total banking sector NPLs increased from 87.3 percent in June 2016 to 94.9 percent in June 2017 while the proportion of banks' NPLs attributable to the public sector declined from 12.7 percent to 5.1 percent over the same period [24].

The restructuring of the Tema Oil Refinery (TOR) and Volta River Authority (VRA) debts accounted for the decline in the public sector's share of NPLs during the review period. Most private sector non-performing loans were debts of indigenous enterprises accounting for 77.2 percent of total NPLs in June 2017, from 73.0 percent in June 2016. The three largest sectors in terms of outstanding credit balances, namely, the Commerce \& Finance, the Services and the Electricity, Gas \& Water sectors, accounted for 63.6 percent of total NPLs in June 2017 compared with a share of 65.7 percent in June 2016 [24]. The share of NPLs attributable to the Commerce \& Finance sector (the sector accounting for the largest share of NPLs) declined from 42.4 percent in June 2016 to 36.8 percent in June 2017.

The Agriculture, Forestry \& Fishing sectors were however the sector with the highest proportion of loans (39.3 percent) being classified as non-performing as at end-June 2017 [24]. It was followed closely by the Commerce \& Finance Sector with a sectorial NPL ratio of 30.3 percent. The observation that Agriculture, Forestry \& Fishing sector leads in default rates and hence non-performing loans constitute a major challenge to Ghana considering the fact that the sector already received less loans due to its perception as being risky. Bank of Ghana data suggest the private sector alone accounts for about $96.9 \%$ of non-performing loans in the banking sector [25]. Though the 2019 fiscal year saw some reduction in the level of non-performing loans, the figures are still on the high side for an efficient banking sector. The Governor of Bank of Ghana stated that, "although the NonPerforming Loans (NPL) ratio has declined from 23.5 percent in April 2018 to 18.9 percent in April 2019, it remained high and points to the industry's exposure to credit risk" [26]. In absolute terms, the year 2019 recorded a total Non-Performing Loans of GHф 7.19 billion as at October 2019 as against $\mathrm{GH} \notin 7.14$ billion in the same period of 2018 [26]. Also, the NPL ratio adjusted for the Fully Provision Loss Loan category improved to 8.1 per cent in October 2019, from 11.4 per cent in 2018 [26].

\section{Methodology}

\subsection{Data Source and Description}

The time series data used for the analysis were obtained from the financial soundness and Economic data base of the Central Bank of Ghana. The Economic database of the Central bank of Ghana has monetary data on financial variable at different frequencies ranging from daily to annual. The frequency of all the data sets for this study was monthly covering the period from January, 2006 to December, 2019, which gives 168 data points for the analysis.

The non-performing loan variable was measured in percentage as the proportion of total loans stock declared as overdue and non-recoverable by standard Central Bank definitions. Two profitability measures were readily available, which were the return on assets before tax (ROA) and return on equity after tax (ROE). Both measures were used in the analysis but only ROA was treated as endogenous since the study's focus was the social value of banks which include the amount the contributes to tax revenue in Ghana. The All Share Index is a composite index for all active shares traded on the Ghana Stock Exchange, and reported in absolute term. The monetary policy rate is determined by the Monetary Policy Committee (MPC) as and when the need arises as benchmark interest rate in the financial sector of Ghana. The values are always in percentage and are changed by percentage points. All other main and control variables were in percentages in relation to a standard base determine by the Monetary Policy Committee of the Central Bank of Ghana.

\subsection{Unit Root Testing}

To avoid spurious regression, very significant statistical relationship without any theoretical appealing, normally associated with non-stationary time series data, the time series variables were tested for the presence of unit root. The study used the Augmented Dickey-Fuller (ADF) unit root test which is an improvement over the Dickey-Fuller (DF) unit root test. 
The ADF test assumes that the error terms are independent and identically distributed. The appropriateness for the ADF test was based on its flexibility in allow for the inclusion of drift term or trend terms in the equation based on the observation of the time series plot. The testing process, therefore, started with the inspection of the time series plots for drift or trend stationarity before the ADF was eventually used as a formal test. The time series plot also provided avenue to observed the presence of structural break in a given time series variables. Where results are trending or drift a trend or drift term was introduced. If a time series variable failed the unit root test after the necessary adjustments, lags were introduced or the variable was difference. The estimation technique used cannot accommodate structural breaks and hence any such suspicion leads to the difference of the variable or the use of lag values in the regression analysis.

\subsection{Econometric Model Specification and Estimation Technique}

The unit root test identified that the variables were integrated of different orders as either $\mathrm{I}(0)$ or $\mathrm{I}(1)$. The good news, however, was that all the endogenous variables were stationary at levels or were I(0) variables. Hence the control variables which were not stationary were either lagged or differenced in simultaneous equation model. Since the variables were integrated of different order up to order 1 , it was possible to adopt the ARDL bound testing co-integration procedure. But since the major aims of the study was to evaluate the bi-causality among any three of the endogenous variables, a simultaneous equation model that allow for the inclusion of the other endogenous variables in the right hands of the regression equation was needed. The Seemingly Unrelated Regression Equations (SURE) model was employed as specified in equation (1):

$$
\begin{aligned}
& R O A B T_{t}=\alpha+\beta_{1} N P L_{t}+\beta_{2} N P L_{t}^{2}+\beta_{3} C^{2 O M L R_{t}}+\beta_{4} \text { COMLR }_{t}^{2}+\beta_{5} R O E A T_{t}+\beta_{6} R_{O E A T}{ }^{2}
\end{aligned}
$$

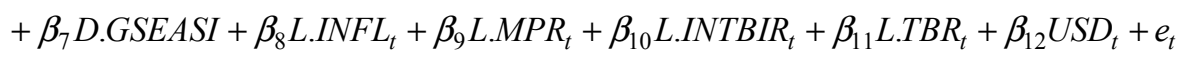

$$
\begin{aligned}
& N P L_{t}=\theta+\lambda_{1} R O A B T_{t}+\lambda_{2} R O A B T_{t}^{2}+\lambda_{3} C O M L R_{t}+\lambda_{4} C O M L R_{t}^{2}+\lambda_{5} R O E A T_{t}+\lambda_{6} R O E A T_{t}^{2} \\
& +\lambda_{7} D . G S E A S I+\lambda_{8} L_{I N F L_{t}}+\lambda_{9} L . M P R_{t}+\lambda_{10} L_{I N T B I R_{t}}+\lambda_{11} L . T B R_{t}+\lambda_{12} U S D_{t}+\varepsilon_{t} \\
& C O M L R_{t}=\eta+\phi_{1} N P L_{t}+\phi_{2} N P L_{t}^{2}+\phi_{3} R O A B T_{t}+\phi_{4} R O A B T_{t}^{2}+\phi_{5} R O E A T_{t}+\phi_{6} R O E A T_{t}^{2} \\
& +\phi_{7} D . G S E A S I+\phi_{8} L_{I N F L_{t}}+\phi_{9} L \cdot M P R_{t}+\phi_{10} L_{I I N T B I R_{t}}+\phi_{11} L . T B R_{t}+\phi_{12} U S D_{t}+\omega_{t}
\end{aligned}
$$

Where ROA (return on assets before tax), NPL (nonperforming loans) and COMLR (commercial banks' lending rate) are the endogenous variables of interest in this study and right hand side contain the respective exogenous variables each model. $\alpha, \theta$ and $\eta$ were the respective constant. Also, $\beta_{i}, \lambda_{i}$ and $\phi_{i}$ are the respective slope coefficients that were estimated and $e_{i}, \varepsilon_{i}$ and $\omega_{i}$ are the error terms. The error terms were very crucial to the estimated method used for the estimations. The SURE model rest on the assumption that feedbacks in the endogenous variables can be captured in the errors terms of the model. Hence, the SURE model treat each model as a separate regression model but adjust for the simultaneity using the connections among the three error terms. The fact that the estimation used the level equations instead of the reduced form of the structural equation forms the basis for referring to the procedure as seemingly unrelated regression equations (SURE) model (Zellner, fact that it accommodates the level variables of all endogenous variables in the respective equations. The SURE model also allows for different repressors to be introduced in different equations in the same system.

\subsection{Testing for Lag Structure (Maximum Lag Length Selection)}

One of the challenges in specifying an optimal lag length ( $\rho$ ) for a model is that if it's chosen lag length is too small, it is possible the model may be mis-specified due to the omission of relevant variables and if too large, it is possible the number of degrees of freedom may be lost. In other words, models with relatively large number of lags are most likely to produce residuals that approach the white noise process, but might not be parsimonious. On the other hand, models with smaller lag lengths is more likely to be parsimonious, but might not produce residuals that are randomenough to approach a white noise process.

The above problem implies that there is the need to select an optimal lag length $\rho$. The Schwartz Bayesian information Criteria (BIC) and the Akaike information Criteria (AIC) are identified in literature as appropriate in selecting optimal lag lengths that produces errors that approach a white noise process, subject to the constraint that the smallest number of lag terms will be selected for parsimony but AIC tends to choose large numbers of lags. Instead, for VAR models, BIC is preferable.

\section{Results and Discussion}

Unit root test of time series variables

The stationarity of time series variables are very key to every time series analysis. That is, the choice of appropriate model to be estimated depends on the stationarity of the time series variables as well was their order of integration. This study did not adopt a traditional time series model, but rather 
a simultaneous equation model that allow for the use or inclusion of time series variables. The seemingly unrelated regression model allows for the use of time series variable and still achieves a consistent estimate. Without notwithstanding that, the stationarity of the variables is key to the consistency of the model. The ADF unit root test was used to test for the stationarity of the variables. The graphical inspection of the three endogenous variables were presented before the unit root test was conducted, which help to determine whether there is the need to introduce a time trend or a drift term in the ADF test.

The figure below presents the time series plot of return on assets before tax (TROA).

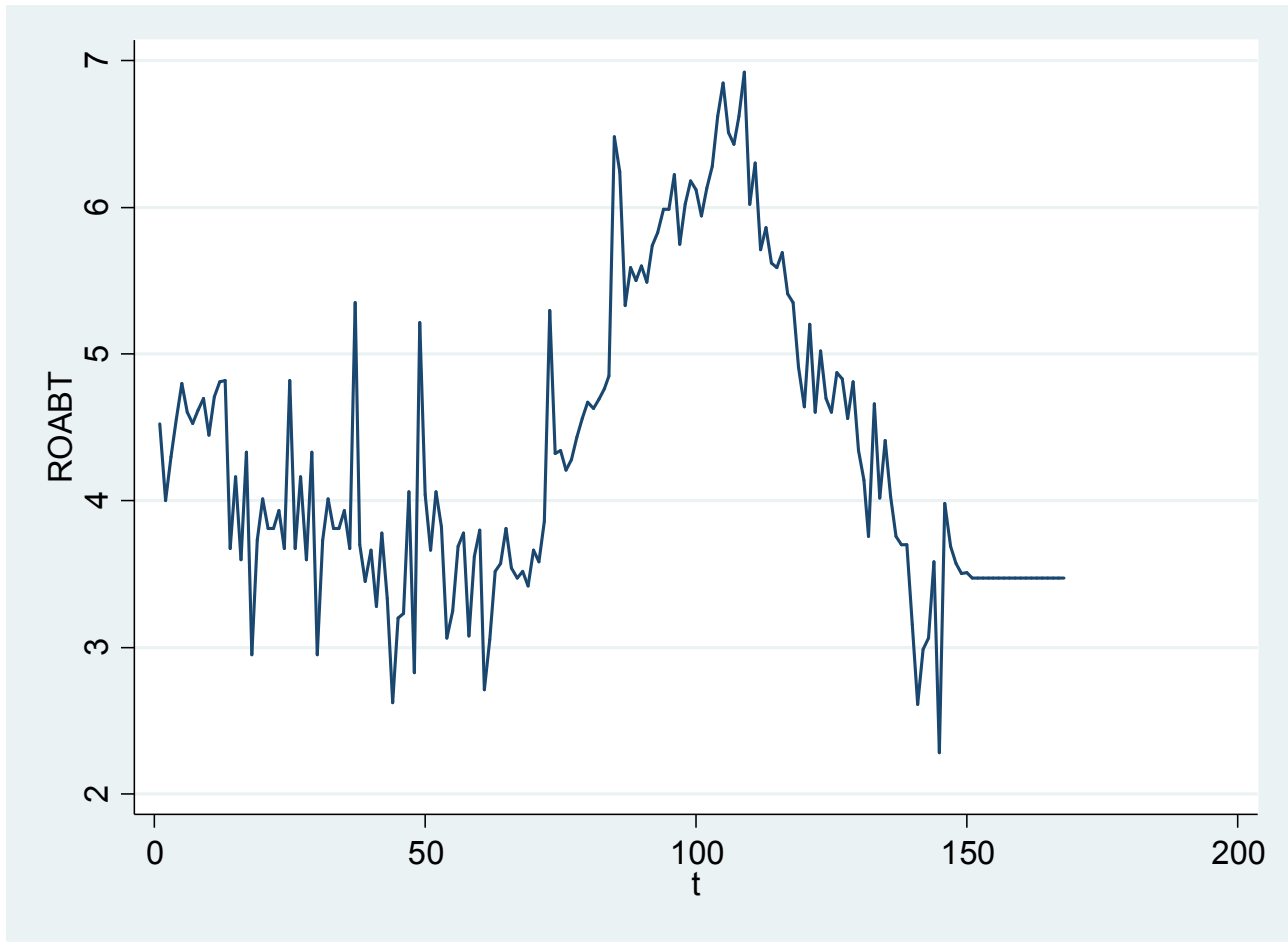

Source: Author's Construct (2019)

Figure 1. Time series plot of return on assets before tax (TROA).

Table 1 presents the ADF test results of the three endogenous variables along with the test of the other control variables.

Table 1. Unit root test of main variables of the study.

\begin{tabular}{lllll}
\hline Variables & ADF Statistics & $\mathbf{5 \%}$ critical value & p-value & Order of Integration \\
\hline ROA & -3.531 & -2.886 & 0.0072 & $\mathrm{I}(0)$ \\
ROE & -4.762 & -2.886 & 0.0001 & $\mathrm{I}(0)$ \\
NPL & -1.721 & -1.655 & 0.0436 & $\mathrm{I}(0)$ with drift \\
Commercial banks' lending rate & -1.817 & -1.654 & 0.0355 & $\mathrm{I}(0)$ with drift \\
Inter-banks' rate & -12.495 & -2.886 & 0.0000 & $\mathrm{I}(1)$ \\
MPR & -14.666 & -1.654 & 0.0000 & $\mathrm{I}(1)$ \\
T-bill rate & -10.160 & -2.886 & 0.0000 & $\mathrm{I}(1)$ \\
Inflation rate & -9.150 & -2.886 & 0.0000 & $\mathrm{I}(1)$ \\
USD exchange rate & -15.872 & -3.441 & 0.0000 & $\mathrm{I}(1)$ \\
GBP exchange rate & -16.399 & -3.441 & 0.0000 & $\mathrm{I}(1)$ \\
Euro exchange rate & -20.795 & -2.886 & 0.0000 & $\mathrm{I}(1)$ \\
GSE-ASI & -11.569 & -2.886 & 0.0000 & $\mathrm{I}(1)$ \\
\hline
\end{tabular}

Source: Author's Construct (2019)

The results in Table 1 show that all the endogenous variables are integrated of order zero, and hence stationary at levels. That is, the return of assets and return on equity variables were stationary at levels without any treatment but the non-performing loans variables was stationary after the introduction of a drift terms and a lag. The commercial bank lending rate was also drift stationary at levels and hence integrated of order zero. All the order variables were integrated of order one, which suggest that they were stationary only after first difference. 
Table 2. Descriptive statistics of main variables for the study period (2006-2019).

\begin{tabular}{llllll}
\hline Variable & Obs & Mean & Std. Dev. & Min. & Max. \\
\hline ROA & 168 & 4.33 & 1.03 & 2.28 & 6.92 \\
ROE & 168 & 23.47 & 5.06 & 7.32 & 34.01 \\
NPLS & 168 & 13.88 & 4.80 & 4.45 & 23.45 \\
Commercial banks' lending rate & 168 & 23.89 & 3.56 & 16.10 & 31.40 \\
MPR & 168 & 17.40 & 3.97 & 12.50 & 26.00 \\
91day T-bill rate & 168 & 16.78 & 6.74 & 0 & 27.80 \\
Inter-banks rate & 168 & 16.70 & 6.06 & 0 & 25.51 \\
GSE-ASI & 168 & 3656.49 & 2623.00 & 969.03 & 10890.80 \\
Inflation & 168 & 12.81 & 3.68 & 7.60 & 20.70 \\
Inter-banks rate & 168 & 16.70 & 6.06 & 0 & 25.51 \\
USD Exchange rate & 168 & 2.55 & 1.47 & 0.91 & 5.54 \\
GBP Exchange rate & 168 & 3.75 & 1.78 & 1.59 & 7.26 \\
Euro Exchange rate & 168 & 3.13 & 1.56 & 1.09 & 6.16 \\
\hline
\end{tabular}

Source: Author's Construct (2019)

The results in Table 2 show that return on assets before tax (TROA) for banks in Ghana was about 4.33 with a spread of 1.03. These results suggest that, on the average, every cedi value of assets could generate about 4.33 cedis in value to the banking sector of Ghana. The minimum ROA was about 2.28 while the maximum was about 6.92 . The return on equity after tax (ROE) had an average value of about 23.47 with a spread of 5.06 within the same period. This suggests that, on the average, every cedi from equity could generate returns of about 23.47 cedis in the Banking Sector of Ghana. The minimum ROE was about 7.32 while the maximum was about 34.01 . The high equity value could be due to the fact that the banks may be using more debts than equity within the study period which results in smaller equity value that results in high return on equity. That is, as a denominator, low equity value could results in high return on equity with relatively small returns.

The average non-performing loans (NPLs) for the period were around 13.88 percent with a spread of about 4.8 percent. The monthly non-performing loan could be as low as 4.45 percent and as high as 23.45 percent. Considering the fact that the percentages are on the entire Banking Sector, the observed percentages could be very high in absolute terms and could explain why non-performing loans was always cited as one of the major reasons for the recent bank reforms in Ghana.

The average Commercial Banks' lending rate was about 23.89 percent with a spread of about 3.56 percent. The lending rate ranges from 16.1 percent to 31.4 percent within the study period. Compared to other developing countries, the lending rates of Ghana are mostly on the higher side. One possible explanation form the data was the fact that the monetary policy rate (MPR) which averaged between 12.50 percent and 26.00 percent within the same period is enough to cause the commercial banks' lending rate to be as high as observed. That is, as a benchmark interest rate, no Commercial Bank that depends on the Central Bank for liquidity shall charge a lending rate below the monetary policy rate. Another possible explanation is the higher rates on Treasury bill rates, which averaged about 16.78 percent and could be as high as 27.80 percent. That is, there are no rational economic reasons for Commercial Banks to charge a rate below the risk free rate to a relatively risky customer base. Finally, the relatively high inter-banks rate also has a role to play in the high average lending rate in Ghana. The average inter-banks weighted average interest rate was about 16.70 percent with a spread of about 6.06 percent.

The Ghana Stock Exchange All Share Index (GSEAI) had an average of 3656.49 with a spread of about 2623.00. The relatively wide spread in the index could be found in the fact that it could be as low as 969.0310890 .80 within the study period. The average exchange rate of cedi to dollar, pound and euro were $2.55,3.75,3.13$ cedis to one unit currency of the respective currency. The coefficients of variables (mean on standard deviation) were 57.65, 49.84, 27.45 percent respectively, which indicates that the dollar is the most volatile currency in Ghana followed by the euro and the pound. The pound is therefore a consistent strong currency in Ghana. The observations made in the summary statistics could provide insight into some of the observations made in the regression analysis.

The simultaneous relationship between Profit, nonperforming loans and lending rate

The study examined the nexus among the average banks profit before tax, non-performing loans and the Commercial Banks interest rate variables in Ghana. The Seemingly Unrelated Regression Equations was used to estimate a system of three equations with the three endogenous variables.

Table 3. SURE Model with non-performing loans as dependent variable.

\begin{tabular}{llllll}
\hline & Coefficient & Std. Err. & t & P>t & [95\% Conf. \\
\hline Dependent variable =NPLs & & & & & \\
ROA & 15.20765 & 2.837368 & 5.36 & 0.000 & 9.632004 \\
ROA2 & -1.307266 & 0.2939834 & -4.45 & 0.000 & -1.884966 \\
\hline
\end{tabular}




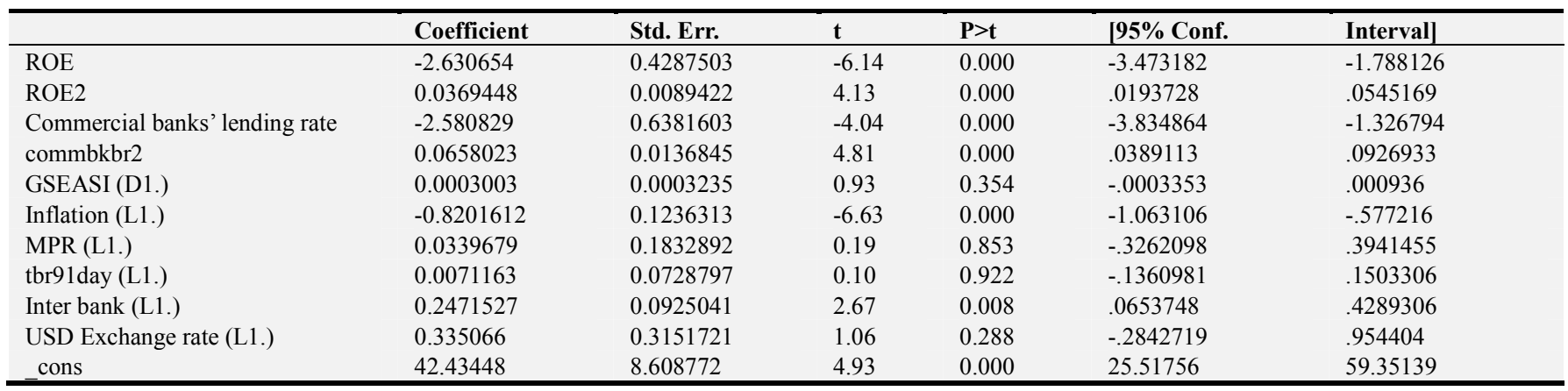

Source: Author's Construct (2019)

The results in Table 3 found significant effects of changes in both return on assets before tax (ROA) and return on equity after tax on the level of non-performing loans in the banking sector of Ghana. That is, at the five percent significance level, ROA have direct but diminishing effects on the level of nonperforming loans. That is, ROA have positive effects on nonperforming loans but the relationship turns negative as ROA increase to a very high level. This observation could be interpreted to mean that as profit maximizes banks increase interest to make more returns which eventually increases the level of non-performing loans, but with sufficiently high returns banks can lower interest in the long run to boost repayment rate as well as organize and offer supports services to clients which shall eventually help them settle their loans. The return on equity after tax (ROE) had negative but increasing effects on the level of non-performing loans, which is opposite to the case of ROA. This observation could be explained by the fact that as predominantly listed banks higher return on equity simply means more dividend pay-out, keeping all other factors constant. Since it is the same part owners who are also the client in most cases, high dividend means increasing propensity of spend and an increase in economic activates. Increase in economic activities and level of endowment can help increase repayment and hence decrease the level of non-performing loans. Using the linear and quadratic term, it was possible to estimate the threshold at which the effects of ROA turns negative and when that of ROE turns positive on non-performing loans. The estimated threshold for ROA was about 5.74 percent and that of ROE was 35.6 percent respectively. The threshold of ROA was within the range of 2.28 to 6.92 and greater than the mean value of 4.33 observed in Table 3 . This suggests that for most banks in Ghana, increases in ROA shall increase the level of non-performing loans. The threshold for ROE was outside the range of 7.32 to 34.01 and above the mean value of 23.47 observed in Table 2. This suggests that the effects on ROE were consistent negatives effects on level of non-performing loans in Ghana within the study period. The two observations explain the role of tax and capital structure on the level of nonperforming loans, since the two are mostly the difference between ROA and ROE. That is, the attempt to Maximization of return on assets before tax (ROA) in order to maximize return on equity after tax has the tendency to increase the level of non-performing loans, which can be largely blamed on high taxes that makes maximization of return on equity after tax difficult. The results also suggest that using more equity instead of debt in the capital structure of the banks shall bridge the gap between ROA and ROE and hence reduce the level of non-performing loans in Ghana.

Table 4. Percentile of commercial Banks interest rate in Ghana.

\begin{tabular}{llllll}
\hline Percentiles: & $\mathbf{1 0 \%}$ & $\mathbf{2 5 \%}$ & $\mathbf{5 0 \%}$ & $\mathbf{7 5 \%}$ & $\mathbf{9 0 \%}$ \\
\hline Lending rate & 19.36 & 21.25 & 23.955 & 26.425 & 28.3 \\
\hline
\end{tabular}

Source: Author's Construct (2019)

Table 5. SURE model with ROA as the dependent variable.

\begin{tabular}{lllllll}
\hline & Coefficient. & Std. Err. & $\mathbf{t}$ & P>t & [95\% Conf. & Interval] \\
\hline NPLS & .3626657 & .08219 & 4.41 & 0.000 & .2011558 & .5241756 \\
NPLS2 & -.0156233 & .0030983 & -5.04 & 0.000 & -.0217117 & -.0095349 \\
Commercial banks' lending rate & .6881833 & .164595 & 4.18 & 0.000 & .3647411 & 1.011625 \\
COMMBKBR2 & -.0170297 & .0035847 & -4.75 & 0.000 & -.0240738 & -.0099855 \\
Inflation (L1.) & .0086498 & .0305755 & 0.28 & 0.777 & -.0514334 & .0687331 \\
MPR (D1.) & -.1139569 & .0823625 & -1.38 & 0.167 & -.2758057 & .0478918 \\
intbkwave (L1.) & .0358367 & .0239869 & 1.49 & 0.136 & -.0112995 & .0829729 \\
tbr91day (L1.) & .0641693 & .0195934 & 3.28 & 0.001 & .0256667 & .102672 \\
USD Exchange Rate (L1.) & .1318627 & .0497993 & 2.65 & 0.008 & .0340032 & .2297222 \\
cons & -5.966984 & 1.96356 & -3.04 & 0.003 & -9.825534 & -2.108433 \\
\hline
\end{tabular}

Source: Author's Construct (2019) 
The results on the percentile distribution indicated that it was only in 10 percent of the cases that the threshold of 19.61 exceeds the average interest rate in Ghana $(19.36<19.61)$, which points to the fact that for about 90 percent of the cases the Commercial Banks' lending rate has the expected positive effects on the level of non-performing loans, keeping other factors constant.

Only inflation rate and the inter-banks weighted average interest rates had significant effects on the level of nonperforming loans at five percent significance level. Inflation had the expected negative effects on the level of nonperforming loans, since high inflation rates makes settlement of debt easier. The inter-banks weighted average interest rate had direct effects on the level of non-performing loans, which was the expectation.

The second model which has profitability measure, ROA, as dependent variable was analyzed in Table 5. The results indicated that the level of non-performing loans had direct but diminishing effects on return on assets before tax (ROA) which confirms the relationship in Table 3. The threshold for the marginal effects indicated that the relationship turns negative after a non-performing loans percentage exceeds $11.61 \%$. The threshold value was below the average nonperforming loans percentage of $13.88 \%$ which suggest that for most cases, increasing the level of non-performing loans has the expected negative effects on the ROA. The Commercial Banks' interest rate on lending also indicated a direct but diminishing effect on ROA. The threshold value was about 20.21 percent, which is below the average lending rate and hence a negative relationship in more consistent on the average. Among the control variables, both the first lags of 91-days Treasury bill rate and USD exchange rate had significant negative effects on the ROA. This observation suggest that past values of 91-days Treasury bill rate and USD exchange rate are important variables in explaining the level of profitability among banks in Ghana.

\section{Conclusion}

The main purpose of the study was to examine the relationship among non-performing loans, Commercial Banks' lending rate and financial performance of Commercial Banks in Ghana. The time series design was used along with the quantitative research approach. Secondary data on the selected variable and some control variables were accessed from the economic and monetary data base of the Central Bank of Ghana from 2006 to 2019 and used for the analysis. Both theoretical and empirical literatures were reviewed to create a research gap for the study. Time series properties of the variables such stationarity and descriptive were done to assess the stability of the time series variables. The Augmented Dickey-Fuller unit-root test was used for the stationarity test since the time series plots indicated no possibility of serious structural breaks. That is the period of the study was entirely within the inflations targeting regimes which saw stability in most economic and time series variables. The analysis explored the bi-causality among the variables hence a simultaneous equation model.

Firstly, return on assets before tax, return on equity after tax, commercial banks interest rate, inflation and inter-banks interest rate were found to be significant determinants of Non-performing loans in the financial Sector of Ghana.

The finding that a positive relationship exists between the lending rate and the level of non-performing loans was a confirmation that Commercial Banks in Ghana dwell heavily on interest income as a major source of income. That is, Commercial Banks' lending rate indicated direct effects on both financial performance of banks but the level of nonperformance loans. Meaning, financial institution may be increasing their financial performance in the short run but may be over-burdening creditors and increasing the chance of default.

Finally, it could be concluded that simultaneous relationship exist among the level of non-performing loans, Commercial Banks' lending rate and financial performance of Banks in Ghana, hence anyone of them could serve as a lead variable or policy variable in ensuring a stable financial system in Ghana.

\section{References}

[1] DesJardins, J. R., \& DesJardins, J. R. (2009). An introduction to business ethics. New York: McGraw-Hill Higher Education.

[2] Ennew, C., \& Sekhon, H. (2007). Measuring trust in financial services: The trust index. Consumer Policy Review, 17 (2), 62.

[3] Cesaroni, T., De Bonis, R., \& Infante, L. (2018). Firms' financial surpluses in advanced economies: the role of net foreign direct investments. Economia Politica, 35 (3), 10551080 .

[4] Maudos, J., \& De Guevara, J. F. (2004). Factors explaining the interest margin in the banking sectors of the European Union. Journal of Banking \& Finance, 28 (9), 2259-2281.

[5] Owusu-Antwi, G., Banerjee, R., \& Antwi, J. (2017). Interest rate spread on bank profitability: The case of Ghanaian banks. Journal of Accounting, Business and Finance Research, 1 (1), 34-45.

[6] Adusei, M. (2015). The impact of bank size and funding risk on bank stability. Cogent Economics \& Finance, 3 (1), 1111489 .

[7] Nyarko-Baasi, M. (2018). Effects of Non-Performing Loans on the Profitability of Commercial Banks-A Case of some Selected Banks on the Ghana Stock Exchange. Global Journal of Management and Business Research.

[8] Alton, R. G., \& Hazen, J. H. (2001). As economy flounders, do we see a rise in problem loans. Federal Reserve Bank of St. Louis, 11 (4), 45-65.

[9] Amuakwa-Mensah, F., \& Boakye-Adjei, A. (2015). Determinants of non-performing loans in Ghana banking industry. International Journal of Computational Economics and Econometrics, 5 (1), 35-54. 
[10] IMF. (2000). International Monetary Fund Annual Report 2000: Making the Global Economy Work for All. ISBN/ISSN: 9781557758439/2227-8915. p. 252.

[11] IMF. (2005). International Monetary Fund Annual Report 2005: Making the Global Economy Work for All. ISBN/ISSN: 9781557758439/2227-8915.

[12] Liu, G., Mirzaei, A., \& Vandoros, S. (2014). The impact of bank competition and concentration on industrial growth Economics Letters, 124 (1), 60-63.

[13] Folajimi, F. A \& Dare, O. E.(2020) Credit Risk and Financial Performance: An Empirical study of deposit money Banks in Nigeria, European Journal of Accounting, Auditing and Finance Research Vol. 8, No. 2, pp. 38-58, Published by ECRTD-UK Print ISSN: 2053-4086 (Print), Online ISSN: 2053-4094 (Online).

[14] Owojori, A. A., Akintoye, I. R., \& Adidu, F. A. (2011). The challenge of risk management in Nigerian banks in the post consolidation era. Journal of Accounting and Taxation, 3 (2), 23-31.

[15] Prochnow, H. V. (1945). The Bretton Woods Bank Program. Sec. Corp., Banking \& Mercantile L., 89.

[16] Ivanovic, A., Bosetti, L., \& Munshey, M. (2016). Fragility, Risk, and Resilience: A Review of Existing Frameworks. UN University Centre for Policy Research, Background Paper, October, 3.

[17] Feijó, Carmem Aparecida. (2011). Credit risk and macroeconomic interactions: Empirical evidence from the Brazilian banking system. Modern Economy, 2 (5), 910-929.

[18] Mac Donald, S. S. and Koch, T. W. 2006, Management of Banking, 6 th edition, U.S.A: Thomson - South Western.
[19] Brown, J. R., Fazzari, S. M., \& Petersen, B. C. (2009). Financing innovation and growth: Cash flow, external equity, and the 1990s R\&D boom. The Journal of Finance, 64 (1), 151-185.

[20] Bank of Ghana. (2008). Overall supervisory and regulatory authority in all matters relating to banking and non-banking financial business with the purpose to achieve a sound, efficient banking system in the interest of depositors and other customers of these institutions and the economy as a whole. Ghana: Accra.

[21] Bank of Ghana. (2020). Daily Interbank FX Rates. Ghana: Accra.

[22] Williams, B., \& Prather, L. (2010). Bank risk and return: the impact of bank non-interest income. International journal of managerial finance.

[23] Kosmidou, K. \& Zopounidis, C., (2008). The determinants of banks' profits in Greece during the period of EU financial integration. Managerial finance.

[24] Bank of Ghana. (2017). Annual report publications. Ghana: Accra.

[25] Larnyoh, K. (2019). An Assessment of the Implementation of the National Policy on Local Economic Development by District Assemblies in Ghana. Journal of Business and Economic Development, 4 (1), 1.

[26] Selassie A. Rich, 2019, BOG Cleanup Mantra and the Fate of Rural Banks: Effects on Financial Inclusion, Modern Ghana, 18.10.19. 